\title{
The Evolution of Sexism: A Modern View
}

\author{
Giorgio Gambirasio,giga@uol.com.br
}

Ana Caroline Saldanha Martins, anacaroline_sm@gmail.com

\begin{abstract}
Possible causes (biological and/or social) for discrimination against women are studied with help of the theory of evolution, starting in time from about two millennia ago (with Australopithecus) up to modern Homo sapiens. The chief cause of sexism appears to be the human male's insecurity before woman natural infidelity. Actual manifestation of sexism was difficult in hunter-gatherer societies, but became fully possible after the Neolithic Revolution.

The sociosexual behavior of primates (gorillas, chimps, bonobos) is used as term of comparison to build up a theory describing arise and spread of sexism in human societies. Monotheistic religions (judaism, christianism, islamism) are shown to have given important contributions to the spread of sexism in western countries.
\end{abstract}

Keywords: sexism, evolution theory, primates, monotheism, Neolithic Revolution, Bible, orgasm, body symmetry, clitoris.

\section{Introduction}

"Sexism is prejudice or discrimination based on sex, especially discrimination against women" according to the Merriam-Webster Dictionary. That our society presents many facets of discrimination against women is certainly a well-known fact and it is not necessary to describe it here. Rather, our interest is directed to discuss and possibly answer such questions as: has sexism biological causes or is it a social construct? is sexism an old or a recent custom (in terms of thousands or millions of years)? how did monotheistic religions interact with sexism?

Sexism also has to do with correlate issues like binary (only exist two opposite, distinct sexes) and gender (differentiation of biological sex from perceived personal sex).

The theory of evolution will be a guide to our investigation. We will start by visiting some of our distant relatives - the modern non-human primates - and observing their sociosexual behavior. The visit will give some suggestion on how Nature intended humans to behave in sexual matters - even as far away in time as two million years ago - and will also answer to questions about how biological causes may have been important for the rise of sexism. The investigation shows that men and women have 
different, contrasting ways of working toward the evolutionary goal of efficiently spreading their genes. In such a difference lie the roots of sexism.

In spite of its biological roots, sexism appears to have been also strongly influenced by social causes. The Neolithic Revolution, when nomadic tribes of hunter-gatherers gave place to sedentary societies, represents an important turning point in the development of sexism.

To complete the picture, in societies where monotheistic religions with a male god (like judaism, christianity, islamism) are dominant, submission of women to men receives religious justification - and sexism becomes a god-given gift to men.

A word about the use of capital initials: too many capital initials in a text interrupt the flow of reading and become a unnecessary nuisance. We shall use capitals sparingly, sometimes against the recommended use. It is all right to capitalize Mediterranean Sea, but the mediterranean diet does not deserve such an honor. A person born in Greece is a greek, speaks greek, carries a greek passport, dances at the sound of greek music. See how ugly such written statement appears when changing "greek" into "Greek".

\section{Sex and gender}

A few years ago — say, about the end of the second millennium - people had these two things for certain: sex and gender. There were two, and only two, possible sexes in the kingdoms of living creatures: male and female — as established in the Bible and especially true regarding human beings. This concept is now called "binary".

And gender was a grammatical property of words like nouns, pronouns, adjectives. Depending on the language, words may have a gender: masculine, feminine or neuter gender. People who wished to speak and write correctly should know the gender of each word they used. Still, gender was an issue mostly restricted to the field of grammarians, otherwise of no concern of the general public.

Well, in the third millennium that situation changed. Since in this paper we study social behaviors that depend on the sex of the actors, we must give some space to mention modern views about sex and gender.

Of course, even in that ancient times some dissonant examples regarding sexual behavior could be found. A few people preferred to choose persons of the same sex to be their partners. Other persons showed a mixture of sexual characteristics like testicles, penis, and full-grown breasts on their body. All those "different" people were regarded in the best case as distorted, wrong products of Nature and in the worst case as sinners to be punished, sometimes even with death penalty. In all cases, they did not belong to the society of "normal" people.

In support to this discrimination, it was claimed that the Bible states that God created all human beings in two, and only two, different, mutually exclusive sexes. Therefore humans must be either a well definite male person or a well definite female person. All other instances are not acceptable - they should surely come from Satan's action.

This scenario has slowly changed because during the transition to the third millennium a series of new facts has emerged. 
First fact: women, tired of being treated as second-class citizens, started to claim for equality, louder and louder; they organized themselves in protesting bodies; a movement called Feminism gave intellectual, social, and active features to the protest.

Second fact: people who - due to psychological or anatomical features — did not fit into the "normality" also started to protest and to organize themselves against discrimination; a group of letters like LGBT (meaning lesbian, gay, bisexual, transgender) symbolized them; as the nonconformist women were already doing, also LGBT people publicly manifested their dissatisfaction and demanded equal place in "normal" society.

Third fact: scientists began to increasingly discover that human beings do not necessarily only have XX chromosomes or only XY chromosomes; other genetic combinations besides XX and XY have been found (like XXY) in the same individual or in different parties of the same body; such combinations may lead to psychological effects (like samesex attraction) or a body with both masculine and feminine external or internal organs. An important article by Claire Ainsworth (Sex Redefined, Nature, Vol. 518, pp. 288-291, 19 February 2015) first brought to the attention of the general public the issue that sex is not binary but rather a spectrum.

Fourth fact: gender quit to be a topic of exclusive grammarian's interest and started to be a much-talked-about set of confusing ideas around how humans may feel their sociosexual position; an imperfect definition would be that sex relates to anatomy, gender to social role.

Well, although written in 2019, the present paper ignores all the above discussions and adheres to the binary concept of two well-defined sexes only. Why? For two reasons. The first reason is that we do not know how LGBT people lived and were accepted, or not, say thirty thousand years ago. The second reason is that societies, when strongly influenced or even ruled by a monotheism, only recognize the different, unfortunate cases as sins. In the King James Version, Leviticus 20,13 states: If a man also lie with mankind, as he lieth with a woman, both of them have committed an abomination: they shall surely be put to death; their blood shall be upon them. In this third millennium, islamic countries condemn to death male homosexuals. Feminine homosexuality is not usually mentioned, probably because of the social and religious insignificance of women in those societies. And about gender: such a discussion is a modern thing which did not exist in biblical and koranic times.

Conclusion: in this paper, all investigations and discussions on sexism will be based on accepting binary and ignoring discussions about gender.

\section{Our distant ancestors}

Between eight and five million years ago, in Africa, some primates started developing certain characteristics which separated them from the strictly simian animals (apes, monkeys) and allowed them to be called hominids, that is, similar to humans. About four and a half million years ago, hominids of genus Australopithecus could no more be confused with simians since they already had human features (although somewhat brute when compared with ours). Australopithecines were mostly vegetarian, occasionally hunters of small animals. Their brain was small, about one third of the size of modern 
humans. They could both climb on trees and walk on the ground. Sexual dimorphism (males greater than females) was high.

Genus Australopithecus disappeared around one million years ago, but not before the arising of our own genus, Homo, whose main species are (in order of appearance): $H$. habilis, $H$. erectus, $H$. neanderthalensis, $H$. sapiens. Of these species, only the last one survives (the one we belong to: $H$. sapiens).

Archaeological discoveries allowed scientists to identify some important features that australopithecines developed along their way from hominids to $H$. sapiens:

a) bipedalism was completed.

b) skull size enlarged, suggesting an increase in intelligence.

c) sexual dimorphism decreased.

d) food variety increased, with an important consumption of meat.

e) discovery of how to kindle and use fire.

f) learning how to manufacture simple tools (made of bones, stones), make pottery, weave vegetal fibers and, much later, to produce and use metals.

To arrive at a more complete picture of how modern humans behave today, we shall make some comments on the preceding listing and add more information, important in understanding how we now act in sociosexual matters. Such changes may have occurred either in the anatomy or physiology or behavior. According to the theory of evolution, genetic changes occur randomly but only those that do not impair survival are kept. The other ones disappear in time.

It is believed that $H$. sapiens first appeared in Africa around one or two hundred thousand years ago and spread over all continents later. These humans lived in small nomadic groups that wandered in search of edible vegetables, roots, fruits. They also hunted small animals and, when the hunters were in a sufficiently large group, killed large animals also (mammoths may have been chased to extinction by this process). Survival was difficult and everyone in the group should help (men, women, older children). There was no established home, people changed place according to abundance or scarcity of food and according to the varying seasons.

Even so, intelligence began to grow, continually so. Why? This process may have been triggered by the pressure to address survival problems when living in an unfriendly environment, and/or as an appeal to the other sex (something like the peacock tail).

In the second case, intelligent people of either sex were attracted by intelligent people, producing more intelligent descendants - a positive feedback that would continue forever unless limiting factors appear. Anyway, brains started to grow in size and skulls indeed had to enlarge correspondingly.

Brain's growth took place in spite of certain disadvantages. A big brain consumes a lot of energy that, in turn, requires much food - a scarce commodity during those times. But the more important consequence was that the growth of the skull made it more difficult for women to give birth to fetuses with ever bigger heads. Nature tried to compensate it by enlarging the pelvis but this solution conflicted with the already established bipedalism. In fact, a large pelvis is a hindrance to staying erect on two limbs only. What to do, then? Would humans (or at least their females) abandon bipedalism and go back to a four-legged gait? No. Nature solved the conflict in another way. Human fetuses started to be born before full development, when their size would not yet demand too large a pelvis. The premature babies were thus forced to complete their development outside of 
the uterus - a fact that turned out to be of great importance for the structuring of human societies.

These babies needed the assistance of adults to survive, this assistance to be given by both parents and for a long time (years!). Such a situation is quite different from what is observed in most mammalian species where cubs or calves start walking and searching for food immediately after birth. The situation is different in another respect also: males usually go away after the female estrus is over and leave the job of providing for the descendants entirely to the females. On the contrary, in humans the need for both parents to take care of their babies became permanently inscribed into human genes. (Of course, the actual behavior of specific individuals is also influenced by other, maybe opposite, genes and other circumstances).

Another difference of the human world from the animal one is that human males do not practice infanticide. Infanticide is a striking instance of how egoist the genes may be. An example is given by the lions: when a lone lion meets a lioness with her cubs, he kills all the cubs. This makes the lioness enter again into estrus, and the lion, mating with her, assures that the new cubs will carry his own genes, not someone else's genes.

By comparison with other primates, it is reasonable to expect that female australopithecines had both ovulation and estrus publicly manifested during their fertile period. Not so with the human females. With base on the theory of evolution, scientists have offered theories on how these changes may have taken place. For example, it has been proposed that hidden ovulation may also be a consequence of developing intelligence - surely a seemingly strange suggestion. Let us explain it: since bearing a child could be an unpleasant, dangerous experience and the more intelligent females noticed that pregnancy happened when ovulating and after sexual intercourse, these women tried to not to have intercourse when being in the fertile period. Such a strategy could cause the more intelligent women not bearing any child, eventually leading to their disappearance. Fortunately, if by some random genetic mutation a woman had a less noticeable ovulation she could become pregnant in spite of her efforts on the contrary. The lesser noticeable the ovulation, the greater the chance of involuntary pregnancy, eventually leading to minimization or even disappearance of perceived ovulation.

It may be stated that modern women's estrus is not publicly manifested but is present all the time. In other words, women's desire or acceptance of sexual intercourse is no more restricted to short periods (the estruses) separated by longer stretches of sexual indifference, but it may extend over all the time. How may it have happened? One theory states that if some random genetic mutation gave an ancient woman a longer estrus (that is, a longer stretch of sexual availability) she had more time to trade sex for food to her and her children therefore setting an evolutionary advantage over her sisters equipped with short estrus. In the long run, the evolution established an almost permanent sexual availability for all women.

\section{Gorillas \& company}

To get a better understanding of human sociosexual behavior we shall look as a term of comparison at some of our evolutionary distant cousins: the non-human primates. We shall try to find correlations between behavior and physical characteristics like sexual dimorphism. Sexual dimorphism is measured by the ratio "male weight/female weight". 
Two different, extreme models are encountered among primates, depending on male sexual competition occurring outside or inside the vagina. Each model is a speciesspecific property, not the choice of single individuals.

An example of male competition outside the vagina is offered by gorillas (Short,R.V. Sexual selection and its component parts ..., Advances in the Study of Behavior, vol. 9, pp. 131-158, 1979). A typical gorilla group is made up of one $200 \mathrm{~kg}$ adult male accompanied by its harem of females and their cubs. Sexual dimorphism is great. Size and strength of the male gorilla keep other males away from the group. Testes represent only $0,017 \%$ of body weight. The penis is relatively small $(3 \mathrm{~cm}$ when erected). Estrus is quiet. Females in the group are submissive to the male.

The opposite model (male competition occurring inside the vagina) is exemplified by chimpanzees. These primates live in groups of about the same number of males and females, without a pronounced social hierarchy. Sexual dimorphism is small, the adults of both sexes weighing around $40 \mathrm{~kg}$. Males have greater sexual organs than the gorillas: testes represent $0.27 \%$ of body weight, penis measures $8 \mathrm{~cm}$ when erect. When a female chimp enters into estrus, she announces the fact by noisy behavior and swelled genitals. She usually mates with all the males of the group.

The following associations or correlations may, therefore, be derived from the above information:

a) male competition outside the vagina is associated with great sexual dimorphism, small male sexual organs, quiet feminine estrus, sultan-and-harem social configuration, brute force to keep male competitors away, females in the harem only mating with one male (the sultan), females always in lower social position than the male.

b) male competition inside the vagina is associated with small sexual dimorphism, great male sexual organs, estrus advertised by females with uproar and great swelling of and strong scenting from sexual organs, females enticing males during estrus, females mating with all males in the group, females in similar social position as males in the group.

An association simply means that certain facts are frequently noticed to occur or run together. It does not imply, per se, any causal link among the facts although of course it does not exclude it. But causality is not under discussion here

We choose sexual dimorphism as the appropriate, easily applicable criterion to guess the position of the human sociosexual behavior in the primate scenario, that is, whether male sexual competition belongs to the "inside the vagina" model or "outside the vagina" model. The ratios "male weight/female weight" pertaining to some important primates are shown below (http://pin.primate.wisc.edu/factsheets):

gorilla $($ Gorilla gorilla $)$ average $=2.18 ;($ from 1.85 to 2.51$)$;

orangutan (Pongo pygmaeus): 2.35;

Australopithecus afarensis: 1.52; (lived around 3.5 million years ago);

Australopithecus africanus: 1.35; (lived around 2.5 million years ago);

chimpanzee (Pan troglodytes): 1.25;

Homo erectus: 1.25 ;

Homo sapiens: 1.22 .

From the latter information we conclude that the low dimorphism in genus Homo suggests a male competition model more similar to chimpanzees than to gorillas. In addition and confirmation, in modern $H$. sapiens testes represent $0.079 \%$ of body weight, middle way between chimps and gorillas; human penis on the average stays at $13 \mathrm{~cm}$ when erected, 
longer than a gorilla's. All this implies that male sexual competition occurs inside the vagina.

Then, why have modern humans not built societies according to the chimps model?

The societies we are referring to are nomadic groups wandering the country as huntergatherers, well before the starting of the Neolithic Revolution. Such societies could have been similar to chimps model but certainly with some important differences. Ovulation was already concealed, estrus may have been less definite and less of public notice. Women's sexual interest had become less dependent on periodicity. However, what was then happening should have been enough to excite masculine sexual jealousy. But in nomadic hunter-gatherer society men could not control efficiently the wanderings of their women. Women had great freedom of movement, consequently also sexual freedom.

Men had to wait for the Neolithic Revolution to be able to unleash their jealousy and start to imprison women, so to speak. The revolution started around 12,000 years ago in the northern part of Mesopotamia. People discovered that it was more practical to put the cattle into a closed space for breeding - and to grow plants and fruits in a garden - than to be eternally nomadic. They stopped running after cattle or searching the country for edible vegetables and fruits; they became settled and started domesticating various plant and animal species. Settlement implies a home, where women stay most of the time and where men are able to control women's movements. Sexism could now prosper - and it sure did!

\section{Reproductive Directions}

Although both sexes are determined by Nature to protect and advance their own genes, they may conflict on how to reach their respective goals. Male reproductive intent is different from woman's because genes are selfish, they do not care for others, they only care for themselves.

It also happens that neither sex is programmed to invest time and energy in taking care of children who do not carry their own genes (this is a fact true in the whole animal kingdom). Let us discuss this conflict with some detail.

Let us start with the Ladies. It is sad, but the cruel reality is that a feminine sexual unfaithfulness increases the protection of female genes. The following model has been proposed as encompassing the possible evolutionary advantages of infidelity.

A theory about how estrus became concealed was presented before and is based on the evolutionary advantages of infidelity, suggesting that such a behavior is even capable of changing feminine physiology.

The husband (or stable partner) may be a good provider (that is the main reason for his existence) but when a woman meets a man whose genetic qualities seem to be better than those of her husband it makes sense for her to have sexual intercourse with him and become pregnant. Their child will be, genetically speaking, a better carrier of her genes. When seen from the evolutionary point of view, this is all that matters.

Another case occurs when a woman may feel afraid of losing her present partner (by his death, or by his leaving her to form a new family with another woman). Why not, then, make a little investment by also extending sexual favors to other men among which a new partner may be chosen if necessary in the future? And with an additional advantage: such new partner may think that some of the woman's children are carrying his genes, not the official partner's genes. This is an advantage, it avoids discrimination against her children. A possible infanticide, not uncommon in the animal world, could represent an extreme 
case of genes egoism. An attenuated, more civilized version of this hostility is encountered in the well known difficult relationship between children and step-parents. Of course, feminine infidelity per se has not necessarily an evolutive justification. When a woman takes a lover to escape a too tedious marital life this fact does not appear to have any evolutionary significance, chiefly when no children result from the affair.

In conclusion, we may now write down a set of Directions by which Nature orients women on how to keep safe and be successful in their reproductive effort. These Directions are genetically transmitted from a generation to the next generation.

\section{Feminine Reproductive Directions}

1. Search for, find and keep a stable partner capable of being a good provider for herself and her children.

2. Always keeping the stable partner, also have sexual intercourse with other men of apparent very good genetic value and try to become pregnant from them.

3. Always keeping the stable partner, also extend sexual favors to other men in exchange for economic advantages now and as an investment toward a more secure future. Since these men are not chosen for their genetic value it is not usually convenient to become pregnant from them.

4. Keep in mind that someone from the group of the above-mentioned men may in the future be chosen as a new partner if the present partner someday fails.

It is seen that the feminine reproductive behavior may be separated into two categories: a) activities directly related to reproduction, that is, getting pregnant from a partner with good genes. These activities represent the older, more primitive, animal-like part of women behavior.

b) activities indirectly (or complementary) related to reproduction, like choosing a good provider as a stable partner (important for her children's survival) and keeping other partners as an investment of insurance. These activities are more human-like since intelligence is required to perform them.

Of course, in actual cases women may not be able to follow the Directions as strictly as Nature prescribes, chiefly in presence of adverse circumstances like the action of jealous men. But they are genetically forced to try.

Why does jealousy not explicitly appear in the feminine Directions? Are women never jealous? Well, they also feel jealousy but for different reasons from what men feel. Women fear that their partners could desert them and form another family - a risk to the propagations of their own genes. Thus such feminine jealousy has evolutionary importance. However, the social expression of feminine jealousy usually has a lesser impact than the masculine one, therefore it has not been included in the feminine Directions. The fear about partner infidelity does implicitly appear in and is taken care of by the third and fourth articles in the feminine Directions. 
After the Ladies, the Gentlemen. Let us now describe the set of Masculine Reproductive Directions.

While the Feminine Directions constitute a coherent set of norms all directed to successfully spread feminine genes, the masculine counterpart sometimes seems contradictory with the mechanisms of evolution. Two facts are central in identifying the Masculine Directions:

a) The first fact: man has a lot of spermatozoids and his goal is to distribute them among the greatest possible number of young and healthy girls (when mating occurs against the woman's will, it becomes rape, a crime punishable in most civilized countries).

As we have already seen, men's bodily characteristics suggest that sexual competition does occur inside the vagina. In fact, the man is well equipped for such a task.

Unfortunately, Nature does not seem to have set provisions for men to always take care of the girl if she becomes pregnant. This is sometimes left as her personal problem; how to survive and feed the children is no man's obligatory concern.

If this rule could be good for many animal species - when their newborns stand, walk, and find food without help immediately after birth - it certainly is not good for humans. Human babies must be fed and cared for during years until they become sufficiently able to survive alone. Therefore, spreading spermatozoids without subsequent care for mother and children does not appear to be consistent with a successful reproductive action.

Fortunately, not all men follow this rule all the time. For personal or social reasons and directed by their genes, some men select "special women" and their children to which they extend food and care, leading to what is called a family.

Not all the women that the savage, brute, sex-hungry men indiscriminately mate with are pure, innocent, helpless girls. There also are the savvy women obeying their Directions, some of them actually wishing to get pregnant if, for example, the male looks suggest his having very good genes - even if these women have a family with a stable partner.

b) The second fact: man is neurotically afraid of women infidelity. This is the key to sexism against women.

It happens that a woman, when pregnant, keeps the carriers of her own genes inside her body. A woman is always sure that her children have her genes. But a man? His precious genes are processed by another body (a woman) and may stay out of his control. In the model of sexual competition inside the vagina, no competitor can ever know to whom belongs the winning spermatozoid.

Once ovulation became concealed and feminine sexual interest was not restricted to a short estrus, a man, when faced with possible feminine infidelity, was left with no means to know for sure whether the children of "his" woman were his children. Moreover, it is a corollary in the theory of evolution that no one wishes to spend time and resources to feed and care for children not their own. The Feminine Directions show that infidelity has evolutionary value therefore infidelities do in fact happen, turning masculine fears fully justifiable. Men's reaction consists in curtailing women's freedom of movement as much as possible. This was a difficult thing to do in a hunter-gatherer society but it has become easier after the Neolithic Revolution.

In summary, masculine jealousy is incorporated into men's genes and is listed in the masculine Directions. Men always tend towards the gorilla model of sultan-and-harem, leaving behind the chimp mode. If men were simians, for this purpose they should increase their sexual dimorphism. A small dimorphism means a lesser social difference between men and women. If modern women eventually win their battle for equality, the gorilla model will never be possible. 


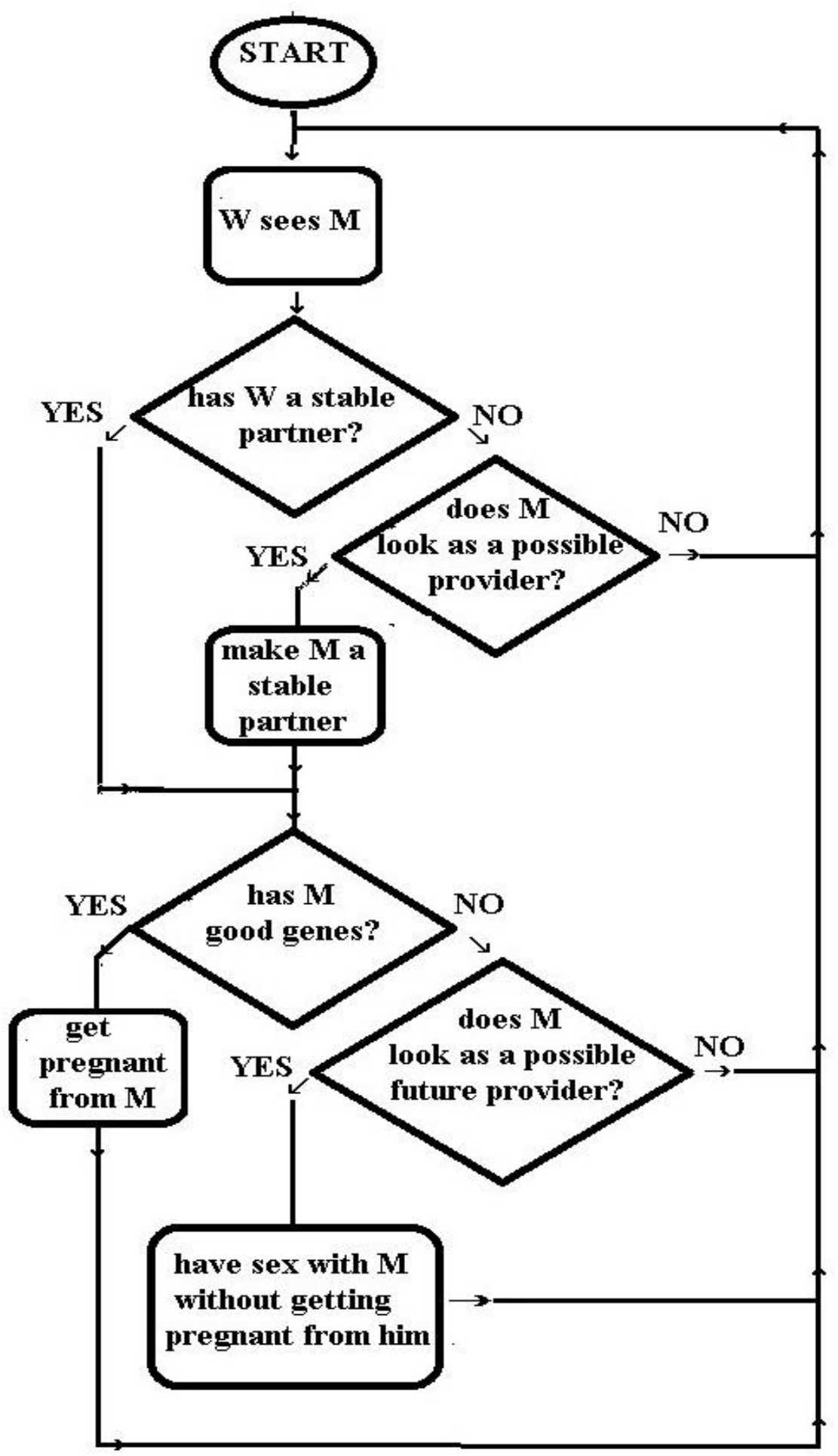

Feminine Reproductive Directions represented on a Flow Chart

Figure 1 - Flow Chart showing how Feminine Reproduction Directions work. 


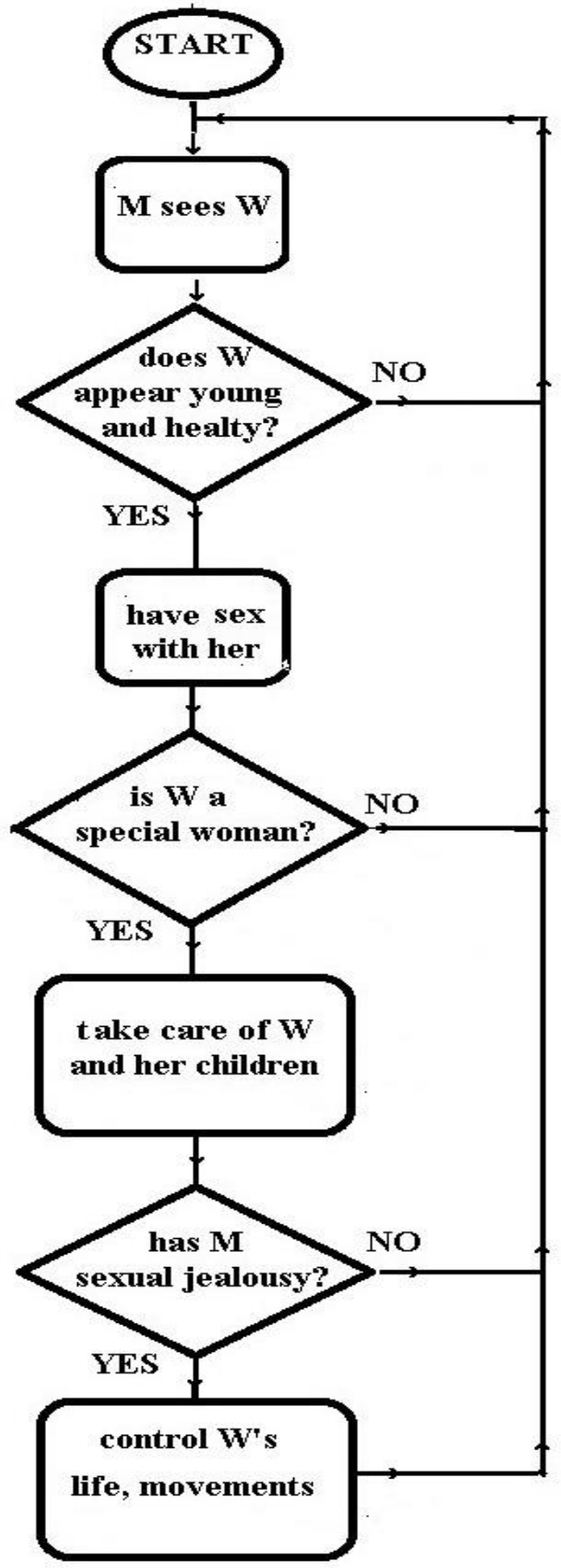

Masculine Reproductive Directions represented on a Flow Chart

Figure 2 - Flow Chart showing how Masculine Reproductive Direction work 


\section{Masculine Reproductive Directions}

1. Mate with the greatest number of women, chiefly young and healthy, without caring for the consequences (pregnancy).

2. With regard to a group of chosen women (the women of interest), give support to and care for them and their children.

3. Block the access of other men to the women of interest.

4. Wholly restrict the freedom of the women of interest.

The two Directions are represented as flow charts in Figures 1 and 2. In them, W represents a generic woman and $\mathrm{M}$ a generic man. The charts show a starting point but no end because the flow goes actually in a loop. The loop goes on forever unless something happens (accidents, poor health, age, menopause, social restraints) to stop it.

\section{Is the orgasm useful?}

To make our work more complete, we will now discuss some other characteristics, bodily or otherwise, pertinent to the object of study. Take orgasm as a first topic. What is the use of orgasm? This is a valid question because a man starts expelling his spermatozoids before reaching full orgasm, a woman may get pregnant without experiencing orgasm. In the masculine case, a full orgasm may be justifiable to increase the chances of fertilization because (as already discussed) masculine sexual competition happens mostly inside the vagina. But in the feminine case? No function at all?

Well, as medicine men of two and half millennia ago suspected and modern research has confirmed, during orgasm the uterus sucks the sperm thus increasing the probability of fertilization. According to this bit of information and the theory that thereby follows, the orgasm has a function, yes, because it acts as a mechanism of choice. A woman who has intercourse with many men may choose the man she wishes to get pregnant from by orgasming with him - and rejecting being fertilized by other less desirable mates by not orgasming with them. And all this happens unconsciously, it is a genetically carried program in the brain.

According to the Directions, a woman should improve the success of her evolutionary task by mating with men carrying good genes. How does she ascertain it? One possible answer is: by body symmetry.

Yes, it has been verified that animals preferably mate with other individuals having great body symmetry. Animal bodies are (or should always look) symmetrical, since the same genes control both halves of the body. The wings, legs, feet, ears, etc., on the left side should be perfect specular images of the corresponding organs on the right side. If present, asymmetry means that something is wrong with the health of the body.

Humans, both men and women, also follow the same criterium to assess a partner's health. Many pieces of research confirm that men's body symmetry has a great correlation with the frequency of being chosen by a woman as a desirable partner for sexual encounters. It was also verified that women orgasm more easily when the man has great body 
symmetry. Finally, it also happens that symmetrical women are more requested for sex (therefore they are more adulterous) than their asymmetrical sisters.

These facts mean that symmetry has evolutionary value; evaluating it is now inscribed in human genes. When the sexual selection was entirely in the hands of Nature, human beauty kept increasing in time. Today, with so much technology interfering in the mechanisms of reproduction and sexual selection, the laws of evolution cannot act freely and the results of sexual selection may be different. Religions may also interfere: as it will be commented later in this paper, in christianity a beautiful woman has been depicted as being the gate of Satan or the road to evil. In a completely christian society, therefore, ugliness would prosper, because ugly people would necessarily mate with ugly people giving birth to uglier children. Discrimination against beauty makes ugliness an evolutionary advantage.

The question of symmetry needs further explanations. It does not mean that women should go around with ruler and calipers measuring and comparing feet, ankles, hands, fists, elbows, and ears of prospective mates. If it sounds ridiculous in humans, it is impossible for birds and fishes. But it is known that birds and fishes make their sexual selections using the symmetry criterion. Is there an explanation? Yes. Symmetry is visible, it is an information assessed by the eye then processed by the brain. In humans, the selection is made unconsciously, the selector does not know that he/she is selecting. In other animals we do not know how the mechanism works. Since animals are not supposed to have that thing called conscience, a word like "unconsciously" may have no meaning there. But many animals surely perform the selection for better genes based on symmetry.

One more consideration: for a woman to process all information about the present partner and make a good decision, her brain needs some time. A too early an orgasm may mix the process up, resulting in a poorer selection.

This consideration would explain why the feminine sexual response is so much slower than the male's. Males are very much interested in quantity, less so in quality. The masculine level of acceptability for partners is definitely lower than the feminine one. Their Directions do not include a very careful choice of partners to fulfill their duty of spreading spermatozoids around because they have plenty of these.

On the contrary, women's supply is limited to one egg per month, therefore women should make the most of it by carefully choosing both the stable partner and those by which they wish to get pregnant.

In summary, the set of feminine Directions is compatible and in harmony with the observational results obtained by researchers.

\section{Delenda Clitoris}

The clitoris is a strange piece in the female anatomy. All female mammals have a clitoris, different in size, shape, functions in different species. What is it, what is it for, what importance has (or not) it in describing sexism? In human females, this organ seems to only have one function: as an instrument of pleasure to women. Even such a simple function, however, has important social implications.

Science tells us that the clitoris is homologous (similar) to the penis. During gestation, that part of the embryo called genital tubercle is responsible for producing either a penis or a clitoris. The choice is commanded by genes and hormones, chiefly by testosterone. 
In non-human primates the clitoris is usually larger and possess more functions than in humans. For example, female bonobos rub their clitoris against another bonobo (male or female) to say "hello!", to calm down spirits and end fights, to show affection.

In another place of the animal kingdom, the hyena (Crocuta crocuta) represents an extreme case of multiple uses of the clitoris. Its clitoris is so long that it may look like a penis to a human observer. It is hollow, and through it the animal urinates, has sexual intercourse and even gives birth! Scientists believe that those exaggerated size and multiple functionalities are due to the high levels of testosterone during gestation.

By comparison with non-human primates, we can reasonably infer that the female australopithecines had greater clitorises than modern human females. A possible explanation for the diminished size is a companion to what has been discussed in the section about orgasm: a small clitoris turns the woman less excitable, she takes more time to orgasm, increasing the possibility of a better, although unconscious, decision about whether getting pregnant from that particular man or not. Taking more time to orgasm therefore making a better choice — is something of evolutionary value.

A second, complementary explanation for a smaller human clitoris has been suggested: ancient human males did not pay much attention to the clitoris, they preferred to look at breasts, waists and other bodily attractions. But a possible masculine indifference does not seem powerful enough to turn a small clitoris into an evolutionary asset. Besides, it is not true that men do not pay attention to the clitoris. We will find that they do, very much they do!

Let us start with an important topic: fear. Men fear feminine independence, power, sexuality, attraction. A man may be scared by the view of a big, protruding clitoris. The vagina itself may look a dangerous place where to nestle one's penis. All this is related to the fear of castration felt by many men. Sometimes female genitals are even supposed to have teeth capable of injuring any unwelcomed penis. Sigmund Freud coined the expression vagina dentata to describe a toothed vagina. Mentions of toothed vaginas are found in folklore tales all around the world. And witches are known to be well equipped with such a complement to their genitalia.

A different form to express disgust with regard to female genitals and clitoris in particular is adopted by african tribes and islamic nations: young girls have their clitoris partially or totally excised, the operation being sometimes accompanied by sewing the vulva's opening. In the last case, the vulva is opened again when the girl marries to allow for sexual intercourse.

What reasons or justifications are offered for the FGM (Female Genital Mutilation)? Of all kinds: social, religious, customs.

When not submitted to FGM, women in the mentioned countries are considered impure, unchaste, becoming an object of social discrimination. They will even be unable to find a husband. In Africa the practice is very old, as reported by ancient greek travelers, therefore predating islamism. A legend from Dogon tribes in Mali (Western Africa) runs as follows: when Amma, the god of Heavens, wished to perform a rite of hierogamy with the goddess Earth, he was stopped by a termite hill (here symbolizing the goddess' clitoris). Only after eliminating the hill could Amma conclude the desired union.

In the civilized western countries FGM has also been practiced, but for different reasons. Parents feel uncomfortable when their newborn girl shows a greater than average clitoris; they fear that the girl might be confused with a boy and be subject to social discrimination; they themselves might suffer from some kind of social criticism or rejection. To avoid 
the discomfort, it has been a common practice in hospitals to downsize the clitoris of the newborn girl to a more respectable appearance (by cutting), therefore ruining her future sexual life.

Being an organ associated with sexual pleasure and masturbation, the clitoris has been frowned upon by conservative and religious people. As it is well known, masturbation is the cause of innumerable physical and mental illnesses, besides also being a mortal sin which quickly sends the sinner to Hell. The solution: FGM on the unfortunate masturbating women!

The clitoris may sometimes have a pernicious effect on human evolution because of its interference on the mechanisms of sexual choice. If a man too efficiently caresses and stimulates the clitoris, the woman may orgasm too soon for her to make the unconscious decision (and perhaps some conscious considerations also) about choosing or not the present partner as the father of her child. It seems that, according to the theory of evolution, not necessarily a good lover is to be recommended as a giver of good genes.

In conclusion, the obvious, natural solution of these problems is delenda clitoris: let the clitoris be destroyed! It is exactly what has happened in the last few millennia.

FGM has a number of advantages when seen from the point of view of a sexist male. It makes women permanently conscious that they belong to a lower kind than males. In certain religions male circumcision means submission of men to a god, correspondingly FGM means submission of women to their true gods, the human males. Since a mutilated woman is strongly discouraged to have sex due to anatomical, physiological, and psychological reasons, she stops to represent a peril to men who are haunted by the thought of not being the father of their woman's children. Such is the golden dream of a sexist man: a woman who is frigid, chaste, obedient, submissive, prolific.

\section{Religion and society}

Religions came up as a psychological defense against forces perceived by humans as uncontrollable. A religion is a set of cultural systems (of beliefs, of practices, of values) dealing with spiritual or super-human beings and their relationship with this world and specifically with humans. Religions establish attitudes and rules to be followed by believers regarding food, social conduct, sexual behavior, rituals of passage and death, fight against illnesses, tales about the origin of the universe and life and what may happen after a person's death. Religions certainly have had an important role in human survival and sexual selection.

Those who deal with sacred things always have ascendancy and dominance over the populace so that religions result in being unavoidably connected with the exercise of power and with money and riches. In fact, even in modern societies it may be noticed that proper and associated religious activities - religious articles, books, schools, radio, television, tourism — represent a multimillion-dollar industry.

Since in this paper we accept the theory of evolution as a working tool to explain some facts of life, we admit to the existence of "religiosity genes". These genes affect how the brain reacts to sacred and spiritual ideas and things. In social-sexual matters, religiosity also interacts with other inherited tendencies like aggressivity, jealousy, and sexuality. Environment and culture give the final touch to how religiosity manifests itself. 
Obviously, religiosity genes do have some evolutionary value, otherwise they would have disappeared. Aggressivity and violence (and not, for example, pleasure) are tools used in sexual competition - maybe because human beings descend from primate species with such a behavior. When humans started imagining superior beings (spirits, gods), they gave those beings also human attributes, including aggressivity. Since religions became systems associated with aggressivity and power, religions are useful for survival (of individuals, persons. groups, entire societies) and transmission of knowledge and values. In societies of low technological level, or when the male role in reproduction was not yet understood, it was a natural thing the appearance of female-oriented religions. A Great Mother stood as a symbol of feminine attributes, like being the source of life and fertility. Later on, when male contribution to reproduction was better understood and, chiefly, when some technological advances occurred (like the advent of the Neolithic Revolution), societies turned male-oriented. Women lost their quasi-divine status and became inferior beings ruled by men.

In polytheistic societies there was room for all kind of superhuman beings: semi-gods; greater gods, lesser gods; masculine, feminine; all kind of spirits, good or bad - and intermediate cases. They were all participants in human lives and destinies. Polytheism implies tolerance in religious matters: you may not like a certain god but you have to accept his/her/its existence.

This picture changes when a religion is monotheistic: in it there is a (usually) male god that thinks of itself as being the only existing god and imposes such belief on all followers and, unfortunately, to non-followers also.

Serving a unique god has some advantage: in a war, since the only god is our god, it will certainly protect us, never our enemies. Our enemies are left undefended, or so we believe.

But monotheism also came to destroy tolerance in religious matters. Intolerance appears not only with respect to other religions (chiefly, other monotheistic religions, the greatest enemies) but also internally to the religion itself. Different sects of the same religion are always in reciprocal fight. As examples, see the catholic/protestant/greek orthodox sects in christianity. Or the shiites/sunnis in islamism.

\section{Monotheism looks at females}

Although greek and roman societies were well into sexism, their polytheistic religion did not reflect such a social attitude. In fact, many powerful goddesses kept their residence on Mount Olympus; their freedom of action was never limited by their belonging to the feminine sex.

Today, the number of those which follow the three monotheistic religions (judaism, christianism, islamism) adds up to more than half of the world population. It is therefore important to ascertain how each respective god relates to the female part of human species.

We shall proceed chronologically, starting with judaism. Our reference in english will be the King James Version (KJV) written with modern spelling. We will write God, with a capital initial, to mean the god of the Bible.

The book of Genesis first states that man and woman were created together (seemingly, with equal status), then immediately the book changes the picture by telling a long story 
at the end of which the woman appears to hold a lower status than the man. In Genesis 3,16, God tells Eve that he [the man] shall rule over thee [Eve].

In Exodus 20, Moses receives some of God's laws like this one: Thou shalt not covet thy neighbour's house, thou shalt not covet thy neighbour's wife, nor his manservant, nor his maidservant, nor his ox, nor his ass, nor any thing that is thy neighbour's.

This law clearly puts a wife among the properties of a man - as an object like a house, or as an animal like an ox or an ass. Additionally, there is no prohibition for a woman to desire anything. But, of course, how could an object or an animal express a desire? According to God's thinking, a woman can be an object of the verb "to desire" but never be the subject. This way of thinking pervades the whole Bible, the woman always being an object, never acting as a subject. Even Solomon's richness was evidenced by the thousand women (objects? animals?) in his harem.

To make things worse, Deuteronomy 22,22 reads: If a man be found lying with a woman married to a husband, then they shall both of them die, both the man that lay with the woman and the woman: so shalt thou put away evil from Israel. A similar statement can be found in Leviticus 20,10. But why should it be mandatory to kill the woman, who is deprived of any possibility or expression of will? If someone steals an ass, it is well to punish the thief but not the poor ass! Well, according to this god, in dubio contra feminam (when in doubt, go against the woman).

A great space is occupied in Leviticus 12-18 to describe woman's bodily impurity or uncleanliness due to menstruation and delivery. It also happens that when a woman is in a state of impurity she transmits the impurity to all objects and persons she touches. Since God appears to abhor an unclean woman, religious services become the exclusive task of male priests.

Deuteronomy 24 informs that a man may divorce his wife whenever he so likes. However, nothing is said about a wife having the right to divorce her husband.

In Numbers 30 it is established that a promise or a vow made by a woman must be validated by the man (father, husband) that has jurisdiction over her. Otherwise, not even God would accept the vow.

In spite of all such disparaging statement the Bible nevertheless recognizes something of value in a woman: her capacity to reproduce. In fact, such capacity is her raison d'être, so much that if a woman is barren, she becomes even more socially worthless. Elisabeth (Luke 1) speaks of her barrenness as "my reproach". And whenever a longtime barren woman becomes pregnant, the fact is seen as a fruit of divine intervention, a proof of God's power. This happens, for example, with Hannah (1 Samuel 1), or Rachel (Genesis $30)$.

Let us go to christianity now, perusing the New Testament. As the jewish, greek, and roman societies were very sexist, it is to be expected that christianism - born and developed in the middle of those societies - also be sexist. According to the KJV, in Matthew 5,17 Jesus states: Think not that I am come to destroy the law, or the prophets: I am not come to destroy, but to fulfil. That is, to make full, to complete, to bring to full realization all that is contained in the Old Testament. Then, let us find out what christianity did to make sexism more complete.

Paul was certainly the great leader in implementing sexism in the christian world. For example, in 1 Corinthians 11 Paul offers a long discourse about whether, when, and how 
men and women should, or should not, cover their head or cut their hair. This presentation is entirely meaningless in the eyes of christian societies of our time but the inner motives are still clearly meaningful, as we can see by reading verses 3 and 7 :

1 Corinthians 11,3: But I would have you know, that the head of every man is Christ; and the head of the woman is the man; and the head of Christ is God.

1 Corinthians 11,7: For a man indeed ought not to cover his head, forasmuch as he is the image and glory of God: but the woman is the glory of the man.

\section{A hierarchical ladder becomes established: at the top, God; then Christ; then man (image and glory of God); and at the lowest rank, woman (simply glory of man)!}

Paul goes on with specifying what should be the proper feminine behavior in church. In 1 Corinthians 14:34-35 he says: Let your women keep silence in the churches: for it is not permitted unto them to speak; but they are commanded to be under obedience, as also saith the law. And if they will learn anything, let them ask their husbands at home: for it is a shame for women to speak in the church. Just about the same things are repeated in Ephesians 5,22-24.

In 1 Timothy 2,8-15 Paul gives more details about the feminine condition according to the Gospel, as follows:

I will therefore that men pray everywhere, lifting up holy hands, without wrath and doubting. In like manner also, that women adorn themselves in modest apparel, with shamefacedness and sobriety; not with braided hair, or gold, or pearls, or costly array; But (which becometh women professing godliness) with good works.

Let the woman learn in silence with all subjection.

But I suffer not a woman to teach, nor to usurp authority over the man, but to be in silence. For Adam was first formed, then Eve. And Adam was not deceived, but the woman being deceived was in the transgression.

Notwithstanding she shall be saved in childbearing, if they continue in faith and charity and holiness with sobriety.

In summary, a woman must dress according to men's instructions, keep silent, remember that Eve was the cause of the Fall; if she bears children, she may be a candidate to salvation.

After Paul, christian men have continued in developing both theory and praxis to improve woman's submission to man, thus following Jesus' effort toward completing the Old Testament. We only find masculine names among the persons shaping the christian thought about sex and woman's social position; no woman was ever invited to (or dared) express the feminine opinion on the feminine position in a christian society.

One of the first apologists after Paul's time was Tertullian (160-220). He wrote many books on theological subjects which helped to structure the catholic church. In these books, he repeats to exhaustion that Eve is responsible for sin having entered human life, that women lead men to the wrong path and similar ones. Tertullian wrote an entire book (De cultu feminarum) to describe how christian women should or should not (mostly) dress and wear ornaments. In another book (De virginibus velandis) he discusses a momentous question, one that (as we mentioned earlier) had also called the attention of Paul: should women cover their head when inside a church? At the end of his book, Tertullian cites, for the edification of christian women, the good example offered by arab 
peoples whose women are constrained to cover head and face (and the suggestion was given well before the rise of islamism).

After Tertullian, during the fourth and the fifth century three men strongly influenced christianism: Ambrose, Augustine and Jerome, all of them saints and doctors of the catholic church.

Ambrose (339-397) was the most important catholic bishop during the reign of the christian roman emperor Theodosius. He was a zealous defender of feminine virginity, as it may be easily seen from the titles of some of his books: Exhortatio virginitatis, De institutione virginis, De virginibus, De virginitate.

Augustine (354-430) is well known for his book "Confessions". In another book (De moribus ecclesiae catholicae) he states that women's submission to men is a consequence of the original sin. Since Augustine considers that the original sin is transmitted by sexual intercourse, he is appointed by some writers as the discoverer of the first-ever STD.

Jerome (349-420) was the famous translator of the Bible into the latin language, the Vulgata. He dedicated much of his life to defend feminine submission and permanent virginity. He also contributed to the spreading of mantras or slogans stating woman's inherent badness, mostly so when she is a physically beautiful creature. One well-known mantra is: Mulier pulchra est ianua diaboli, via iniquitatis, scorpionis percussio: a beautiful woman is a gate of the devil, a path to evil, a scorpion's bite.

In the following centuries after having risen to political power, christian men built a religious-political organization entirely composed and managed by men (the catholic church), one of whose important purposes was the fight against its enemies: the remaining pagans (almost disappearing), all christians belonging to religious sects not catholic (always appearing), the jews (which stubbornly refuse to convert), and women (inferior beings, main cause for men to sin).

The above excerpts and discussions illustrate the jewish and christian contributions to sexism. Islamism is the third important monotheistic religion and we shall read from the sacred, divinely inspired book: the Koran. In the following, a couple of samples.

Among other places, in 4,34 it is stated that: Men are the protectors and maintainers of women, as God has given some of them an advantage over others, and because they spend out of their wealth. The good women are obedient, guarding what God would have them guard. As for those from whom you fear disloyalty, admonish them, and abandon them in their beds, then strike them. But if they obey you, seek no way against them.

That women are intellectually inferior to men is stated in 2,282:

When you incur debt among yourselves for a certain period of time, write it down. And have a scribe write in your presence, in all fairness..... And call to witness two men from among you. If two men are not available, then one man and two women whose testimony is acceptable to all-if one of them fails to remember, the other would remind her.

Obviously, the question of impurity, related to menstruation, is also treated in the Koran. But the most amazing thing in islamism is that woman's social inferiority is not limited to this life, it extends to the afterlife! In fact, it appears that the islamic heaven is only structured for men's pleasure (44,51 and following; 56,20 and following; 78,31 and 
following). Men would have good food and drinks at their disposal, plus a certain number of girls (always virgin, with big eyes and firm breasts) for their entertainment and pleasure. Women will also enjoy good food and drinks but always still in the company of their old husband. But please notice: no young, strong stud is mentioned to make love to them, ever!

Having just described the important points on how the three monotheistic religions treat women, we will present the Woman's Statute - a set of statements that synthesizes the position of women in a society ruled by monotheistic religions. It is of general character, therefore common to the three religions; each religion then puts forward its specific refinements. It also seems that the Statute is the only topic upon which the three religions do not disagree!

\section{Woman's Statute}

Art. 1 - The human female (woman) is a being of inferior character and social status as compared to the human male (man); she is also an object of man's administration or property.

Art. 2 - By her own nature, the woman is an impure being.

Art. 3 - A promise or a vow made by a woman must be validated by the man that has jurisdiction over her.

Art. 4 - The woman justifies her existence by maternity.

Art. 5 - The woman must be constrained by moral and/or physical means to not express her sensuality.

This Statute tranquillizes men in their fear of not being the father of woman's children. Woman's objectification is secured when every woman necessarily stays under a man's jurisdiction (or, even better, when she is a man's property) and she is also considered juridically inapt. Being in a state of impurity in many instances, women are barred from acting as a priestess; they can not produce the sacred, they are only allowed to consume the sacred - and even this with restrictions because of their impurity.

The first four articles come naturally from the previous text but the last article needs some explanation. Article 5 is a reaction to, or a defense from, feminine sensuality. Let us start the explanation by seeing the difference between sexual and sensual.

In animals, sexual activity is directly related to reproduction. When an animal female goes into estrus, she solicits and accepts male attention, otherwise not.

The human female being considered to only be a reproduction machine by monotheistic religions, these religions tolerate woman's sexuality within the limits established by her impurity. Being barren is a curse that increases a woman's social worthlessness.

Sensuality, on the other hand, is an entirely different thing. Sensuality is something that distinguishes civilized human beings from animals; it is something that derives from the development of intelligence; it separates the utilitarian aspect of an activity from the gratification of the senses. For example: when animals are hungry, they eat the food as they find it, raw. No hunger, no eating. 
But human beings separate the utilitarian aspect of feeding the body from the sensuous aspect: they cook the food, they add spices, they garnish it - even when all this does not add any nutritional value to the food. And they even eat sweets when they are no more hungry!

A similar situation is found in sexual activity. Animals are sexual, not sensual. They mate strictly for reproduction. No estrus, no mating. Only human beings separate the utilitarian aspect (reproduction) from sexual pleasure.

The Canon Law of the Catholic Church (1917 edition) in its 1013 canon (article) defines marriage as follows: Matrimonii finis primarius est procreatio atque educatio prolis; secundarius mutuum adjutorium et remedium concupiscentiae. Quick translation: the marriage has two goals; the first goal is parenthood; the second goal is mutual help and remedy against concupiscence. Well, since concupiscence is sinful but reproduction is necessary, sex becomes tolerated by turning marriage into a thing-without-pleasure. Sex is permitted as long as it is not pleasurable.

Why would men fear feminine sensuality so much? Because there is one more, and important, difference between sexuality and sensuality. To be sexual it is sufficient to have the proper instincts and genetic programming, as all animals have. To be sensual, one needs to be a free subject, a free person, able to express desires and feel the sentiment of ownership of his/her body. All such things are incompatible with the model that the monotheistic religions prescribe for the human female.

Art. 5 mentions moral means of constraint, like making sensuality into a sin which offends the god. And powerful physical means of constraint are, for example, keeping women like prisoners at home or, in extreme cases, cutting their clitoris out.

\section{Christianity and the woman}

As it has already been shown, monotheistic religions in general give strong support to female-specific sexism. The tactics of keeping women in a subordinate social state are the masculine reaction to the ancestral fear and jealousy originating from feminine natural infidelity. We shall direct our attention at one specific monotheistic religion: christianism, and chiefly to the catholic sect.

It is possible to identify two aspects of christian sexism. The first one is related to the feminine place in society — and this aspect obviously has many points of similarity with what happens in other monotheistic religions, because it directly comes from men's sexual jealousy. The second aspect is chiefly specific to catholic christianism and is more related to the spiritual area: the masculine fear of losing one's soul due to feminine behavior. As a result, three distinct feminine models play their roles in christian sexism, exemplified by Lilith, Eve, and Mary.

Genesis 1 describes the simultaneous creation of man and woman in God's image; it is not specified from which raw material the first human beings were formed.

Genesis 2 tells a different story: man was created first: And the Lord God formed man of the dust of the ground, and breathed into his nostrils the breath of life; and man became a living soul. The woman was formed later, from a piece of the already existing man's body; neither one of them was made in image of God. 
The two chapters are in contradiction. Or perhaps not, because there may be a gap in the narrative due to some lost part of the scripture which, if known, would explain why Genesis 2 does not conflict with Genesis 1.

Well, there appears to exist an old proposal to fill the gap - and a quite interesting one from the point of view of studying sexism. In an apocryphal (unofficial) document called "Alphabet of Ben Sira", the woman created according to Genesis 1 has a name: Lilith. Lilith was endowed with some egalitarian ideas about her position in the society (a pretty small society at that time, only husband Adam and wife Lilith). Her ideas were against Adam's desire to rule over her, a motive for endless discussions and quarrels between them.

Lilith's egalitarianism appears to be justified, since in Genesis 1 both man and woman were created in God's image, and God established no explicit hierarchy between them.

To end the quarrel with Adam, Lilith leaves Eden and is later transformed into a sorceress, a witch. As Lilith's legend shows, since the very beginning of the world independent and troublesome women are considered witches, that is, some demonic, totally evil creatures equipped with supernatural powers. In many pagan societies witches are condemned to death, as well as in hebrew and christian societies.

But, so the tale goes on as written in Genesis 2, not to let Adam alone God creates a new woman, a helper called Eve, this time no more from the dust of the ground, but from Adam's body. Now an implicit hierarchy is suggested (Genesis 2,23): And Adam said, This is now bone of my bones, and flesh of my flesh: she shall be called Woman because she was taken out of Man. Eve comes out from an already formed creature (... my bones ... my flesh ...), thus suggesting a lower status for the helper. After the Fall, the hierarchy is not simply suggested, it is explicitly declared in Genesis 3,16 .

In the history of western peoples, troublesome women are frequently included in the "witch" or "sorceress" category. As an important example, we now show that the greater a menace women are seen by men in a society (or church), the more frequently "sorcerers" become "sorceresses" in translations of sacred scriptures.

We shall do the exercise of comparing different translations of the same biblical verse (Exodus 22,18, chosen as the working sample) from the greek into latin or vernacular languages. These translations were made in different epochs and into different languages and are related to the historical events going on at the time each translation was issued.

As a first step into the exercise, we need to make a digression to explain the role of translators. Translators became necessary from the moment the biblical god decided to confound their language, that they may not understand one another's speech, as stated in Genesis 11.

Unfortunately, translators are frequently accused of unfaithfulness, of treason. Why? The act of translating is like passing a text through a filter. However, each language has its own characteristics, its own specific idioms, its own dependence on ideas and costumes of a certain epoch. All this makes the filter imperfect. Translating becomes like taking a picture with a camera equipped with slightly deforming lenses. The resulting picture may look good in general but be unfaithful in many important details.

Let us first justify the choice of Exodus 22,18 as the sample biblical verse to be used in our research of sexism along the ages. For all sects of both judaism and christianism there is a common base of faith: a collection of god-inspired sacred scriptures (called the Old 
Testament in christianity). This collection of writings dates from millennia ago and was originally written in hebrew, a language today unknown to jews and christians, except in Israel. So, what and how can the faithful read? It is here that translators enter the picture. The faithful do not actually read the original texts, they read the texts translated into a language they are fluent in. Therefore the importance of translators' role in interpreting the scriptures cannot go without notice. The importance extends to the social consequences of scriptural interpretation.

It happened that, in the last few centuries BC, peoples in the whole area around the Mediterranean Sea were fluent in greek as a second language. Perhaps not a pure greek

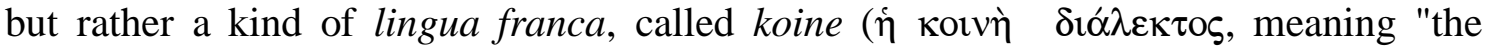
common language"). This description also applies to the roman world, where citizens of the upper classes spoke greek at home and knew homeric poems by heart. Government officials necessarily should be fluent in greek. And anyone wishing to trade goods in the mediterranean area should be able to speak greek because that was the language that almost everybody there understood.

At those times and places, the jewish populations also were fluent in koine but no more in hebrew. Hebrew had become an almost dead language, only known by clerics but entirely forgotten by the common jewish citizens. Such a situation certainly affected the religion and the unity of judaism. So, it was decided by the religious authorities that the scriptures in hebrew be translated into greek, in order that the sacred manuscripts could be read by the entire population, not only by the clerics. It took a couple of centuries but it was done. This translation from hebrew to greek is known by the latin name Septuaginta (meaning "seventy") in reference to the legendary seventy translators that did the work.

This situation stood true even at the times of Jesus. Jesus should have been fluent in greek, and so was Pilatus; for their conversation, no translator was ever needed. All documents of the New Testament are written in greek, and in this language they may be read by us, twenty centuries later. All citations from the Old Testament that are found in the New Testament come from the Septuaginta, obviously the official sacred text of judaism at the time of Jesus.

Since the authors of the present paper are not fluent in hebrew, the Septuaginta will also be taken by them as the primary source for the Old Testament. Therefore the starting point of our research will be Exodus 22,18 as it appears in the Septuaginta.

As time passed and christianism went into power in the mediterranean world, latin eventually became a language more frequently spoken than greek, so that a translation of both Old and New Testament into latin was felt necessary. This translation was firstly made by Jerome, in the fourth century. His work was given the title Vulgata because it was intended to be read by the common people (vulgus in latin).

As we shall see, along the time other translations become necessary because Europe had turned out to be a multi-lingual aggregate of nations and latin itself was slowly becoming a dead language, only known by clergy and upper classes but no more by the populace.

After the digression, let us go back to the sample. In the Septuaginta, Exodus 22.18

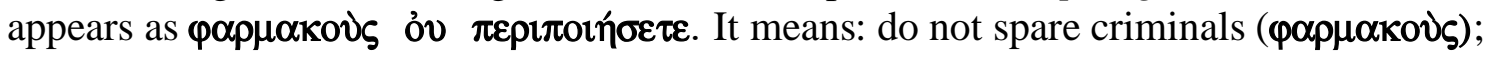
do not let criminals go unpunished.

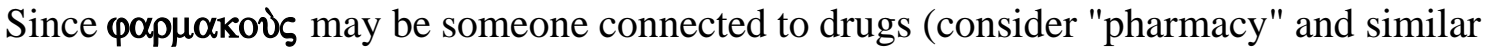
names in english), it is possible that the recommendation be a reference to magicians, 
sorcerers and like individuals of doubtful reputation. The name is a masculine name; in a broader sense, it may also include women, of course.

Then, when Jerome was working on his Vulgata, he duly translated that sentence into maleficos non patieris vivere. Again, a masculine name (maleficos), strictly following what was written in the Septuaginta.

About a millennium later, the protestant reformation having already taken place, Martin Luther decided to make his own translation of the Bible, which he published in 1545. In Luther's translation, Exodus 22.18 reads: Eine Zauberin darfst du nicht am leben lassen. But Zauberin is definitely a feminine name, which would translate as "witch" or "sorceress" in english.

This new choice of word means that those persons, who according to the Septuaginta were criminals to be killed (possibly magicians but certainly men and women), now according to Luther they should strictly be witches, strictly women. But why?

Let us offer a possible explanation, to be confirmed or not by the examples to follow. Protestantism, in freeing men from the social and religious dictatorship of the catholic church and in motivating them to read the Bible themselves and make their own interpretation of the sacred texts, may have influenced women also to follow suit. And to be able to read the Bible and to teach it to their children, women needed some education, at least learning to read (latin and vernacular), write, and maybe do some arithmetic. So in early protestantism women started to get a better education than their catholic counterparts, chiefly in the poorer classes. At the same time, those women began demanding increasing participation in social and religious matters, but this new attitude was not welcomed by the men. What was written in the hearts of pastors and husbands is that a woman is an object created by their god to be inferior to and ruled by a man. And if some of them women protest too loudly, let them be called Zauberinnen! Protestantism chiefly aimed to put pastors in the place of priests, certainly not to change the structure of a male-dominated society. Translators may also be speakers for their times!

Some years after Luther's Bible, the King James Version (1611) appeared as the official translation into the english language according to anglican thinking. Exodus 22.18 was rendered as: "Thou shalt not suffer a witch to live". The same thing as Luther had done. Again, why?

When Henry VIII had the Parliament approve the Act of Supremacy (1534), making the monarch of England the Supreme Head (changed to Supreme Governor in 1558, during the reign of Elizabeth I) of the Reformed Church of England, he also opened the possibility to a woman (a queen) to hold such title and exercise such function. That is, there would exist a kind of "female-pope" to head the Reformed Church of England (Elizabeth I was the first queen in that office). To sexist englishmen, however, to have a woman as head of their church certainly was a most unpleasant thing to bear. This is reflected in the King James translation.

Notice that Luther's protestantism is quite different from Henry's reformation - both in their causes and practical expressions. Luther had entirely religious motivations, while Henry was only moved by personal, political reasons. But the underlying, profound, genetic reason for the sexism is the same: masculine discomfort in face of feminine freedom and power.

At the same time as Luther, Henry VIII and others declared their independence from the papal rule, the Catholic Church started its movement of counter-reformation. This included issuing a new translation of the Bible, a revised and updated version of Jerome's 
Vulgata. The new version became known as Vulgata Clementina because it was started to be published in 1592 when Clement VIII (pope from 1592 to 1605) was in charge.

At those times the Catholic Church was entirely sure about woman's position in the catholic world and christian sexism was an established, god-commanded, eternal truth. A few feminine libertarian movements were restricted to protestantism and did not affect catholicism in any way. Therefore, when reviewing Jerome, the Clementine version let Exodus 22.18 again read maleficos non patieris vivere. No mention to witches here. Good. But why? Because at those times and places catholic women definitely presented no peril of libertarian thoughts. In the catholic world sorcerers (that is, both malesorcerers and female-sorcerers or sorceresses) were not allowed to live. In the protestant and anglican world, however, only sorceresses were to die, not sorcerers in general.

Well, time passed, and in the twentieth century the Catholic Church decided to issue a second updated version of the Vulgata, published in 1979 with the title Nova Vulgata.

In the meantime, revolutions happened, cultural environments changed, and sexism started to be attacked by women even inside some catholic communities. Women began gaining voting rights in most nations. Feminist movements became every time and everywhere noisier and noisier. The Church felt the peril.

Pope Paul VI (Marialis cultus, 1974) exhorted "the modern woman, anxious to participate with decision-making power in the affairs of the community" to instead look at Mary for inspiration and example. John Paul II followed suit (Mulieris dignitatem, 1988; "Letter to Women", 1988) with similar arguments.

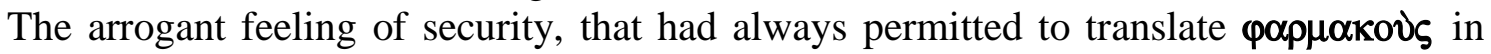
Exodus 22,18 with its true meaning of a masculine name, was now giving its place to another choice. The Nova Vulgata of 1979 translates Exodus 22,18 as maleficam non patieris vivere, that is, with a feminine noun: maleficam.

At the long last, even catholicism adhered to sexism in translation!

So, the statement presented earlier is proven true! The greater a menace the feminine world represents to men, the more cases of sorceresses-to-be-killed appear in the translation of Exodus 22,18 !

As for Paul, he cooks up a truly misogynistic solution for the contradiction between Genesis 1 and Genesis 2. From Genesis 1 Paul selects "man is God's image" but he carefully forgets that the woman also is so endowed. From Genesis 2, he acknowledges the transforming of Adam's rib into a woman but fails to notice that no mention whatever to a possible likeness to God appears there, either in benefit of Adam or of Eve. Finally, from Genesis 3 Paul gets the information that, as a punishment after the Fall, the man shall rule over the woman. The conclusion reached by Paul's choices is that women are designed by God to be creatures inferior to and submitted to men. And to such an effect Paul wrote 1 Corinthians 11,7.

So much for the social aspects of christian sexism. Let us now consider the spiritual aspects. It happens that, in christianism, by some strange mechanism masculine insecurity with regard to female faithfulness even invades the spiritual sphere: men's salvation may be seriously compromised by feminine behavior.

Perhaps the mechanism is not so strange. In fact, the religion insists on considering all things sexual (acts, thoughts, behavior) as expressions of a capital sin labelled "concupiscence". An extreme consequence of this is that a christian man may actually sin simply when he pleasurably looks at a beautiful woman. 
"Devil's gate, road to evil, scorpion's bite" are some of the words which christian religious leaders use to describe and salute a beautiful woman. In fact, a woman who also happens to be a beautiful creature represents an added peril, because she may, from the simple fact of being beautiful, easily excite masculine concupiscence - therefore causing the unfortunate sinner to quickly be sent to a well-deserved place in Hell.

Conversely, there is no hidden or explicit caveat against women being led into temptation and sin by some handsome and seductive man. Why so?

It seems that the difference between the two sexes extends to their souls. Even without going so far as to proclaim that women have no soul (as a few medieval theologians once did), it is clear that in christianity women are treated differently from men also with regard to spiritual matters. One important consequence of this state of things is an added discrimination against women: the salvation is not offered to men and women on equal terms. From the point of view of the offering god, men's salvation is more important than women's. The simple look of women may hinder man's salvation, but not vice-versa. Should it be so because of women's natural inferiority? Is a woman's accidental beauty to be considered an act of intentional disobedience of divine law, a subtle tentative to escape from masculine dominance? In doubt, says the divine law, keep it against the woman (in dubio contra feminam).

The feminine model that both shields christian men from women sexual unfaithfulness and keeps masculine souls away from sinful concupiscence is represented by Mary. Mary's model is entirely free from concupiscence, that is, she is sexually frigid. Her frigidity is the guarantee that she will never show any interest in men. Her husband (or owner) may feel entirely sure that Mary's children are all also his children. She is totally submissive - an example to all women. Since a woman must never appear desirable to men, not even to her husband (otherwise she would induce him to sin), Mary's model carries modesty to the highest degree. She is always represented totally covered except face and hands, resembling hebrew and arab feminine fashions. Not even her hairdresser knows the color of her hair. And certainly she is fertile - otherwise all the abovementioned concerns and cares would have no meaning if she were incapable of bearing children.

The case opposite to Mary's is the model represented by Lilith. Lilith is not submissive at all. On the contrary, she wants equal status with men. She has normal sexuality and behaves according to the Rules that Nature (or evolution) has given to her. Therefore, modesty is none of her goals.

Obviously, Lilith is fertile. And she is not a witch! Such an attribute is unjustly given to Lilith by masculine sexism.

As for Eve, she represents the common christian woman. She stays in between the two models, Lilith and Mary. Nature pushes Eve towards the model of Lilith. Masculine sexism pushes Eve towards the model of Mary. In any actual case, what happens to a common woman depends on circumstances - society, family, religion, and her personality.

\section{Women's responsibility}

It is of course an evil thing to blame the victims for their disgrace. But it is also important to notice that the spread and permanence of sexism in human societies could not have happened in such a large scale without an important feminine cooperation. Simone de 
Beauvoir in "The Second Sex" observes that oppressors would not be as strong without help from the oppressed.

As an attenuating circumstance, it may be said that men so strongly succeeded in inculcating women with sexist ideas that sexism became the normality even in civilized societies. In all monotheism-dominated societies women educate small children to their future role as sexist adults: boys to be the masters of women, girls to be the subjects of men. This comes from very old times.

In ancient Greece, Athens and Sparta represented two opposite positions concerning the social roles assigned to upper-class women. For example: athenian little girls were served one half the quantity of food as boys got; most of them were left illiterate; women could not hold property, therefore wives did not inherit from the husband.

Among the works of the famous orator Demosthenes one can find the speech that Demosthenes pronounced in the process that he and a certain Apollodorus moved against the hetaera Neaera (book 59, section 122 of Demosthenes works). The speech contains a statement about the position of women in the upper classes of Athens as seen by their husbands:

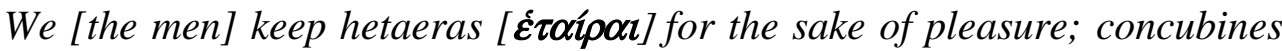

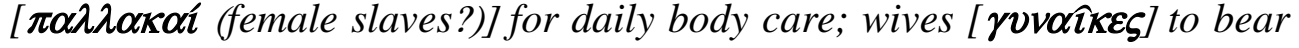 legitimate children and to take care of the house.}

Conversely, quite different from the athenian was women's social position at Sparta. At Sparta, the corresponding examples are: the same quantity of food for boys and girls; the same education for boys and girls; spartan women could hold property and inherit from the husband. Therefore it seems that spartan society was a bit less sexist than the athenian one.

Who was the philosopher well satisfied with the athenian example but who did get angry when considering the spartan paradigm? No one less than Aristotle! In his treatise "Politics", chiefly in Book II, Aristotle states that the indulging of women in any particular liberties is hurtful to the end of government and the prosperity of the city. According to Aristotle, the fact that spartan women held a large part of properties would increase the lust for riches: when the manners of the women are not well regulated, as I have already said, it must not only occasion faults which are disgraceful to the state but also increase the love of money. (The translations are taken from Project Gutenberg).

As we know it, spartan women were criticized outside Sparta for wearing dresses considered too short. Taken together, all these facts would depict Sparta as a femaledominated, greedy, wanton, immoral city-state. Such are the conclusions that Aristotle arrives at.

Curiously, the adjective "spartan" has had, since time immemorial, quite a different meaning. The Merriam-Webster Dictionary states that "spartan" means "marked by simplicity, frugality, or avoidance of luxury and comfort", or "marked by strict selfdiscipline or self-denial".

In his "Politics", Aristotle also gives us a quite interesting bit of information. Lycurgus (the legendary king that in the ninth century BC structured the spartan constitution) was stopped by protesting spartan women from any attempt to tame them: but we are told, that when Lycurgus endeavored also to reduce the women to an obedience to his laws, upon their refusal he declined it. It should be encouraging news to present-day 


\section{feminists to know that three millennia ago a group of decided women successfully refused to submit to male dominance!}

In another place and time, we find a terrible example of feminine adhesion to sexism. In african and/or islamic countries the excision of the clitoris is performed on young girls by the elder women. This barbaric practice is an old social custom that local women insist in following and spreading, an alleged reason being that a non-excised girl is "impure" and as such she would never get married.

All the cases cited here represent a few, different examples where feminine submissive collaboration have been important factors in the spreading of sexism across many cultures.

\section{Conclusions}

A conclusive summary may be presented with help from the sketch in Figure 3.

Titled "The saga of sexism against women", the sketch illustrates how woman's social value has changed with time, going from a couple of million years ago (time of Australopithecus), through Homo sapiens, to the present days and also towards a possible future.

At the top of the figure, a number of descriptive words suggest important events that occurred at the approximate date given by the word position on the time scale.

An early great dimorphism between masculine and feminine bodies suggests, as we saw, a submissive female population. At those times, humans were hunters of small animals and gatherers of wild fruits and vegetables. When the Homo genus appeared, fire started to be used and greater animals were hunted. An increasingly diminishing sexual body dimorphism signaled an increasing feminine social value in $H$. sapiens' nomad huntergatherer communities. Those times possibly correspond to the best ever social equality between male and female humans in the entire H. sapiens history.

At the same time, a great change was maturing, so great that it has been labeled a revolution: the Neolithic Revolution. Some anthropologists think that it was the women's more developed observational power what permitted the discoveries that led to the revolution. Anyway, the revolution turned against them. An important consequence of permanent settlements was that women were now at hand when men wanted to give a strong social expression to their disbelief of feminine sexual faithfulness. Women started losing more and more of the freedom they had enjoyed before.

When in some countries monotheistic religions appeared and rose as dominant social powers, women's social value in such countries sunk to its minimum value.

Later, in Europe, intellectual movements like the Enlightenment and revolutions like the French Revolution brought again the feminine inferiority under discussion. Women started to protest. Feminism grew as a strong movement no more possible to be ignored. For the present and the near future, the sketch shows a grey area of possible outcomes. Religious fundamentalist societies will go on keeping their women at the lowest possible social level; more civilized countries will allow a steady increase in feminine social value, at last bringing it, ironically, to the situation existing among our savage ancestors a few tens of thousand years ago. 


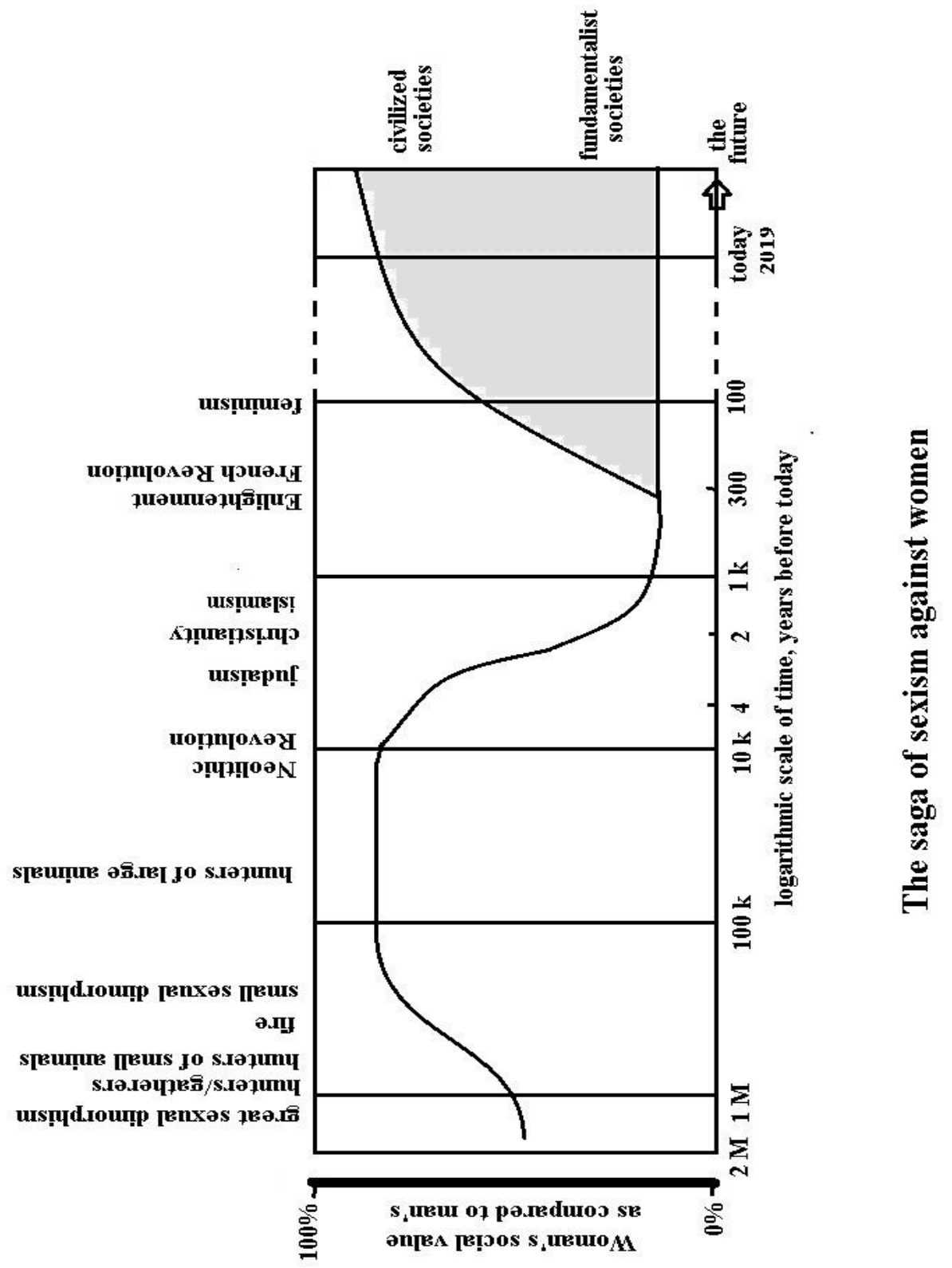

Figure 3 - A sketch showing how sexism changed along the last two million years

\section{Acknowledgment}

The authors whish to thank Ms. Neusa Popinigis for her help in revising the text. 